\title{
New Research on Early Modern Ukraine: Foreword
}

\author{
Giovanna Brogi
}

University of Milan

C

Conferences and panels have become an "ordinary way of life" for researchers, and it may appear idle to remember one of the hundreds of similar academic gatherings in Slavic and Ukrainian studies. Nonetheless, the conference held on 14-15 January 2019 in Naples is worth recalling. Today, as we continue to fight the COVID-19 virus, we may remember those days as a happy period when people could freely travel, talk, socialize, and discuss ideas, findings, and plans in the field each one of us knows and loves. The stay in Naples was beautiful, enhanced by some sightseeing and gastronomical pleasures. Thanks to Maria Grazia Bartolini and other members of the Italian Association for Ukrainian Studies (AISU) Alessandro Achilli, Simone Attilio Bellezza, and Marco Puleri-we had a remarkable pre-dinner drink in a charming coffee shop in the very heart of Naples's intricate (and intriguing) downtown. It seems like ages ago, but those days are engraved in my memory as a recent joyful event. I wish to express here my gratitude to the mentioned Italian scholars of the younger generation, who organized the event, which was sponsored by the University of Naples Federico II, the Italian Association for Ukrainian Studies, and the Italian Association of Slavists (AIS).

I am also grateful to the participants who came from various countries and represented, on the one side, the crème de la crème of Ukrainian studies, and on the other, some of the most promising scholars of the future-the generation in their 30 s and $40 \mathrm{~s}$ - who will continue the job of us "elders." Fortunately, they change, revise, and introduce new methods, ideas, and points of view. I am personally very proud of my former students-not only the best ones whom some colleagues know well, but also the dozens of other students who took just one course on Ukrainian literature and language out of simple curiosity, stimulated by the events of the 2000s and 2010s, by the Orange Revolution of 2004-05 and the Euromaidan/Revolution of Dignity of 2013-14. With very few exceptions, they were all Italians, a point which, in my view, is extremely important for a healthy development of sound research and teaching of Ukrainian literature, language, and culture in Italy and beyond.

The conference in Naples was remarkable, mainly for the high quality of the presentations. Allow me to name such outstanding specialists as George 
G. Grabowicz, Georgiy Kasianov, Stanislav Kul'chyts'kyi, Marko Pavlyshyn, Tatiana Tairova, and Alois Woldan-established scholars who presented on the "classics" of literature and culture, but also those from the younger generation, dealing with new social, political, and cultural issues concerning Ukraine and the international background, such as Olga Bertelsen, Nataliya Borys, Mayhill Fowler, Olga Gnydiuk, Svitlana (Lana) Krys, and Eleonora Narvselius. The presented papers often challenged established knowledge and ideas, in many cases offering fresh information and material, or addressing new issues and unexpected situations.

I hoped to be able to offer for publication a considerable number of papers. As often happens in such events, the presentations were followed by lively discussion. However, the content of most was already in print or designated for other publications. While we are able to present only two of the Naples conference papers here, they both make important contributions to the field of Ukrainian studies, and I am pleased to introduce them. I will begin by noting that both are devoted to early modern Ukrainian (or Ruthenian) subjects. This reassures me that philological studies are not declining and, on the contrary, continue to offer fruitful results. The rigour with which these scholars carry out their research demonstrates a continued willingness to overcome the inherent difficulties of coping with old texts and devoting oneself to long-lasting, often complicated (and some may even think boring!) subjects.

Maria Ivanova's paper approaches the work of the well-known, antitrinitarian writer Szymon Budny (ca. 1530-93) from a new point of view. She analyzes the paratexts, more specifically Budny's marginal notes, placing them in a theological context. She then focuses on their significance for the reception of patristic legacy. Ivanova has found a new, fifth book, which belonged to Budny, Mystagogical Catechisms by Cyril of Jerusalem. The Latin translations of Cyril's works and Budny's marginal notes indicate how important it was for the antitrinitarian thinker to submit to criticism the terms used by Catholic translators of the Counter-Reformation. As a true humanist, Budny fostered etymological analysis and exact understanding of the significance of words for a non-dogmatic, truthful interpretation of the legacy of the Church Fathers. The aim of reformed thinkers was not only a return to the original Apostolic Church, but also to the original meanings of words. The comparison of the original Greek words with the Latin translation shows how important Cyril's works were for Budny, not only for his anti-Catholic polemics, but also for the theory and practice of translation itself. However, Budny's numerous annotations and partial corrections also indicate the importance, for this Ruthenian thinker, of comparing the Catholic, Orthodox, and Patristic words for establishing the correct use of such important sacraments as baptism and communion. Even such "worldly" issues as the legality of participation in war (in polemics with the Polish 
Brethren) find their way into Budny's comments. Ivanova's deep analysis highlights the perspicuity of the Ruthenian reformer's analytical mind, the depth of his linguistic knowledge and philological skills, but also the complexity of his religious thinking, the fluidity of his beliefs, and the inclusive nature of his approach to the many confessions of his time, a time when "masks" and "protean mentality," "ars excerpendi" and "ars dissimulandi" were rather the rule than the exception. The way of "living on the margins," as Ivanova writes, makes Budny a character we may consider not so distant from our own troubled times.

Dieter Stern devoted his paper to a subject he has investigated for many years, which, however, seems to present a growing number of unanswered questions rather than easy solutions. Stern studies religious devotional songs from the point of view of the rationale that may have inspired compilers and collectors of such songs in the Ruthenian lands and in Muscovite Russia in the seventeenth-eighteenth centuries. The author tries to answer the curious question of why there was a lack of manuscripts or prints of devotional songs in Ukraine while collections of songs were present in Russia in the 1670s-80s. To arrive at a possible answer, Stern applies various methodological approaches, ranging from the numerical data of songs chosen for transcription or print, to social issues concerning the various classes who might be interested in writing down and possessing collections of songs, to religious concerns of possible compilers, buyers, and owners, and, finally, to analysis of the mentality and economic situation of potential owners of manuscripts or printed collections. Stern's analysis provides new evidence for the distinct perception of devotional songs in Ruthenia and Russia. They were perceived as "exotic," basically "foreign" items for a rich elite in Russia in urban milieu. In Ruthenia, on the contrary, they pertained to the traditional patrimony of all confessions as a cherished object of memory with some regional flavour of belonging and a dominant rooting in peasant and low clergy milieu. One of the reasons for the lack of written collections in the Ruthenian lands in the last decades of the seventeenth century may be found in the fundamentally oral transmission of the songs. They slowly penetrated church services, offering parallel ways of singing with "official" liturgical hymns. At the end of the seventeenth and in the first half of the eighteenth century, song collections written down by wandering seminarians (mandrivni diaky), or other literate alumni of the Kyivan Mohyla Academy, gained prestige in the Ruthenian lands and were considered desirable objects and cherished memories. Many other questions and answers given in this paper offer an erudite, but also pleasant, reading for anyone interested in early modern culture and in new approaches and methods for further investigation.

These two papers bear witness to the high level of the conference. They are highly specialized, dense, erudite, and, at the same time, reader-friendly 
in the clarity of their argumentation. They are rooted in the best European philological tradition but draw fresh and stimulating lifeblood from methodological paradigms of the broader social context. Studies in medieval and early modern literature and culture seem to have gained momentum in recent years and are represented by outstanding young scholars. I appreciate the many new contributions to contemporary literature and culture that appear, and I cannot conceal that it gives me great satisfaction to read papers such as the ones we publish here.

Last but not least, I wish to thank Svitlana (Lana) Krys, the editor of EWJUS, for publishing these two papers and for the diligent work she put in to ensure the articles were edited and published. 